\title{
HAK ANAK DITINJAU DARI HUKUM DAN HAK ASASI MANUSIA
}

Oleh:

\author{
Elviana Sagala, SH, M.Kn \\ Dosen Tetap STIH Labuhan Batu \\ e-mail : elviana.sagala77@yahoo.com
}

\begin{abstract}
ABSTRAK
Akhir-akhir ini kekerasan terhadap anak-anak sering terjadi, bahkan banyak yang menyebabkan kematian, seakan-akan hak asasi manusia yang menempel pada anak di abaikan, dan seakan-akan anak-anak itu merupakan permainan yang tidak perlu dilindungi. Kita tidak menyadari dan sering lupa bahwa anak adalah karunia Tuhan yang sangat istimewa yang harus di jaga dan merupakan generasi penerus yang tidak boleh hilang dari bumi ini sebab jika tidak ada anak berarti musnahnya kehidupan selanjutnya. Hasil dari penelitian yang dilakukan yaitu diperlukan adanya perubahan status dari undang-undang perlindungan anak yang ada saat menjadi undang-undang yang istimewa serta perlu adanya revisi terhadap undang-undang hak asasi manusia yaitu memasukan hukuman mati. Karena hukuman mati adalah satu satunya hukuman yang wajar bagi pelaku kejahatan terhadap anak yang membuat anak cacat seumur hidup dan mati.
\end{abstract}

Kata Kunci : Hak Anak, Perlindungan Anak, Hak Asasi Manusia

\section{PENDAHULUAN}

Hak Asasi Manusia adalah hakhak mendasar yang dimiliki oleh manusia yang harus dilindungi, karena manusia merupakan makhluk Tuhan yang memiliki banyak kegiatan untuk kelangsungan hidup dan juga untuk mempertahankan keturunan juga agama dan keyakinannya. Dalam pasal 1 Undang-Undang Nomor 39 Tahun 1999 tentang HAM disebutkan bahwa "Hak Asasi Manusia adalah seperangkat hak yang melekat pada hakekat dan keberadaan manusia sebagai makhluk Tuhan Yang Maha Esa dan merupakan anugerah-Nya yang wajib dihormati, dijunjung tinggi, dan dilindungi oleh negara, hukum, pemerintah dan setiap orang, demi kehormatan serta perlindungan harkat dan martabat manusia.
Pengakuan akan Hak Asasi Manusia di Indonesia telah tercantum dalam Undang-Undang Dasar 1945 yang sebenarnya lebih dahulu ada dibandingkan dengan Deklarasi PBB yang lahir pada 10 Desember 1948. Pengakuan akan Hak Asasi Manusia di Indonesia telah tercantum dalam Undang-Undang Dasar 1945 dan peraturan perundang-undangan lainnya adalah sebagai berikut:

1. Pembukaan Undang-Undang Dasar 1945 Alinea Pertama

2. Pembukaan Undang-Undang Dasar 1945 Alinea Keempat

3. Batang Tubuh Undang-Undang Dasar 1945

4. Ketetapan MPR

Untuk dapat berkembang tentu manusia harus melangsungkan hidupnya 
dengan memiliki keturunan. Tentu saja manusia sangat ingin dilindungi karena manusia itu hidup dengan aturan yang dibuat oleh manusia berbentuk aturan, seperti Indonesia merupakan negara hukum yang setiap orang tidak dapat melakukan sesuka hatinya walaupun itu untuk melindungi keturunannya. Oleh karena itu tentu hak-hak tiap manusia itu harus dilindungi dan harus dapat bertahan hidup.

Dalam Undang-undang Hak Asasi manusia terdapat 15 Pasal tentang Hak Anak yaitu Pasal 52 sampai dengan Pasal 66 salah satu pasalnya yaitu Pasal 52 berbunyi yaitu ayat (1) setiap anak berhak atas perlindungan oleh orang tua, keluarga, masyarakat dan negara, ayat (2) hak anak adalah hak asasi manusia dan untuk kepentingannya hak anak itu diakui dan dilindungai oleh hukum bahkan sejak dalam kandungan. Pasal 53 ayat (1) setiap anak sejak dalam kandungan berhak untuk hidup, mempertahankan hidup dan meningkatkan taraf kehidupannya, ayat (2) setiap anak sejak kelahirannya, berhak atas suatu nama dan status kewarganegaraan. Pasal 54 yaitu setiap anak yang cacat fisik dan mental berhak memperoleh perawatan, pendidikan, pelatihan, dan bantuan khusus atas biaya negara, untuk menjamin kehidupannya sesuai dengan martabat kemanusiaan, meningkatkan diri, dan kemampuan berfartisipasi dalam kehidupan bermasyarakat dan bernegara. Pasal 55 yaitu setiap anak berhak untuk beribadah menurut agamanya, berpikir, dan berekspresi sesuai dengan tingkat intelektualitas dan usianya dibawah bimbingan orang tua dan atau wali. Pasal 56 yaitu ayat (1) setiap anak berhak untuk mengetahui siapa orangtuanya, dibesarkan, dan diasuh oleh orang tuanya sendiri, ayat (2) dalam hal orang tua tidak mampu membesarkan dan memelihara anaknya dengan baik dan sesuai dengan undang-undang ini, maka anak tersebut boleh diasuh atau diangkat sebagai anak oleh orang lain sesuai dengan ketentuan peraturan perundang-undangan. Hak asasi anak dalam pasal-pasal tersebut menguraikan tentang hak-hak anak tetapi tentang terjadinya pelanggaran hak atas anak tersebut yang dimaksud UndangUndang Hak Asasi Manusia tidak ada dijelaskan. Undang-undang Hak Asasi Manusia diundangkan 23 September 1999 dan Undang-Undang Perlidungan anak baru dibuat tahun 2004 yaitu UndangUndang Nomor 23 tahun 2004 yang kemudian dirubah menjadi Undangundang Nomor 35 Tahun 2014 Tentang Perlindungan anak. Yang didalam undang undang tersebut pasal 1 angka 12 berbunyi Hak anak adalah bagian dari hak asasi manusia yang wajib dijamin, dilindungi, dan dipenuhi oleh orang tua, keluarga, masyarakat, negara, pemerintah dan pemerintah daerah. Dengan melihat 
hal ini Penulis merasa bahwa hak manusia terutama dalam hal untuk perlindungan hak anak begitu sangat memperihatinkan, karena undang-undang hak asasi Manusia yang telah membuat hak-hak anak yang harus dilindungi baru diundangkan 5 tahun kemudian dan di perbaiki lagi 10 tahun kemudian. Karena itu penulis ingin membuat tulisan mengenai hak asasi manusia yang berkaitan dengan hak anak yang harus menjadi prioritas utama karena merupakan generasi penerus bangsa, tentu harus benar-benar dijaga dengan baik dan sesempurna mungkin sehingga naka-anak tumbuh sesuai dengan kebutuhan negara kesatuan Republik Indonesia.

\section{METODE PENELITIAN}

Metode penelitian yang digunakan pada penelitian ini yaitu menggunakan metode Yuridis Normatif yaitu mengacu kepada ketentuan ketentuan peraturan perundang-undangan positif di Indonesia khususnya peraturan perundangan tentang perlindungan anak dan Hak Asasi Manusia.

Dalam penelitian ini, akan diteliti data sekunder. Dengan demikian ada dua kegiatan utama yang dilakukan dalam melaksanakan penelitian ini, yaitu studi kepustakaan (Library Research), yang diperoleh melalui kepustakaan, dengan mengkaji, menelaah dan mengolah literatur, peraturan perundang-undangan, artikel-artikel atau tulisan yang berkaitan dengan permasalahan yang akan diteliti.

\section{PEMBAHASAN}

Anak adalah makhluk Tuhan YME yang harus dilindungi dan dijaga hingga tumbuh dengan sempurna dan melanjutkan hidupnya dengan baik dan normal. Anak juga merupakan karunia Tuhan yang sangat berharga dari apapun bentuknya, sehingga kadang banyak cara yang dilakukan oleh setiap pasangan untuk dapat memiliki keturunan. Sungguh hal yang sangat menyakitkan hati bahkan membuat hati setiap orang akan menjerit dan marah bila ada seorang ibu kandung dan ayah kandung membunuh atau menyiksa anaknya sendiri..

Peraturan perundang - undangan di Indonesia yang mengatur tentang ketentuan anak adalah:

1. Kitab Undang - undang Hukum Perdata ( KUHP )

2. Staatsblad 1917 nomor 129 tentang adopsi

3. Undang - undang nomor 1 tahun 1974 tentang perkawinan

4. Undang - undang nomor 4 tahun 1979 tentang kesejahteraan anak

5. Konvensi hak anak yang diratifikasi pada tahun 1990

6. Undang - undang nomor 23 tahun 2003 tentang perlindungan anak

7. Hukum Agama atau kitab suci agama

8. hukum Adat 
Pemberian perlindungan kepada anak di dalam hukum perdata sangatlah penting karena hukum perdata mengatur hak anak sama seperti orang dewasa sebagai anggota masyarakat, anak juga memperoleh hak. Namun anak - anak tidak dapat melindungi hak -haknya saperti orang dewasa, oleh karena itu diperlukan bantuan orang dewasa untuk mengurusi hak - haknya. Oleh karena itu perlindungan anak sangatlah penting.

Dalam hukum perdata, kriteria penggolongan anak ada 2 macam yaitu menurut batasan usia dan perkembangan biologis, menurut batasan usia, untuk hukum tertulis yang terdapat didalam hukum perdata berbeda - beda tergantung dari perundang - undangannya. Menurut BW dan Undang - Undang Nomor 4 Tahun tahun 1979 tentang kesejahteraan anak yang termasuk dalam kriteria anak adalah mereka yang usianya dibawah 21 tahun dan belum menikah.

\section{Menurut Undang - Undang}

Nomor 1 tahun 1974 tentang perkawinan yang termasuk dalam kriteria anak adalah mereka yang usianya dibawah 16 tahun untuk perempuan, dan 19 tahun untuk anak laki - laki. Menurut konvensi hak anak yang termasuk dalam kriteria anak adalah mereka yang usianya lebih dari 18 tahun ( kecuali apabila kedewasaan anak telah ditentukan lebih awal ), atau dibawah 18 tahun tetapi sudah menikah. Menurut Undang - Undang Nomor 23
Tahun 2002 yang telah di ubah menjadi Undang-Undang Nomor 35 Tahun 2014 tentang perlindungan anak yang termasuk dalam criteria anak adalah mereka yang usianya kurang dari 18 tahun.

Menurut perkembangan biologis untuk hukum tidak tertulis seperti yang diatur dalam hukum islam dan hukum adat. Contohnya dalam hukum islam dilihat dari tanda - tanda biologis seperti seorang anak laki - laki dikatakan dewasa apabila anak laki - laki tersebut telah mimpi basah. Dan dalam hukum adat dilihat dari tanda - tanda kemandirian dari anak tersebut, seperti dalam suku jawa, seorang anak dikatakan dewasa apabila anak tersabut sudah bekerja dan menghasilkan uang.

Dari ketentuan batasan usia anak dapat disimpulkan yang dikatakan anakanak adalah anak yang masih berusia dibawah 18 tahun. Berdasarkan hasil penelitian Penulis banyak ditemukan kasus kekerasan terhadap anak seperti kasus penganiyaan terhadap anak balita berusia 1,5 tahun yang dianiaya Ibu kandungnya hingga meninggal dunia yang kasusnya di tangani PPA Polres Metro Bekasi kota, di daerah Kuningan Jawa Barat anak SD usia 8 tahun dianiaya Ibu kandungnya yang vidionya viral dimedia sosial, di Kembangan Jakarta Barat seorang Baby Sitter menyiksa naka majikannya yang masih berusia 2 tahun dengan cara menggigit bayi tersebut, dan 
yang sangat viral pemberitaannya adalah penganiyaan yang terjadi pada Angelie anak yang berusia 8 tahun di daerah Denpasar Bali yang ditemukan mati terkubur dikandang ayam dan tubuhnya penuh luka dan bekas jeratan tali dilehernya, juga pembunuhanan anakanak dalam kardus di kalideres Jakarta Barat korban pembunuhan dan pelecehan seksual oleh kerabat ayah kandungnya sendiri, hal ini sangat luar biasa dan sangat menyakitkan untuk derita oleh seorang anak yang harusnya dibesarkan dengan penuh kasih sayang.

Hukum adalah suatu sistem yang dibuat manusia untuk membatasi tingkah laku manusia agar tingkah laku manusia dapat terkontrol, hukum adalah aspek terpenting dalam pelaksanaan atas rangkaian

kekuasaan kelembagaan, Hukum mempunyai tugas untuk menjamin adanya kepastian hukum dalam masyarakat. Oleh karena itu setiap masyarat berhak untuk mendapat pembelaan didepan hukum sehingga dapat di artikan bahwa hukum adalah peraturan atau ketentuan-ketentuan tertulis maupun tidak tertulis yang mengatur kehidupan masyarakat dan menyediakan sangsi bagi pelanggarnya begitu dan banyak lagi kasus yang menimpa anak-anak lainnya yang tak dapat Penulis uraikan satu persatu yang merupakan hal yang sangat luar biasa. Hal ini adalah merupakan kasus yang harus diatur khusus dan penanganannya harus istimewa, dengan arti bahwa hukuman bagi pelaku tidak lain adalah hukum mati dan tidak ada pilihan lagi. Untuk itu Penulis berharap agar para pembuat undang-undang dapat kembali merevisi tentang Hak asasi Manusia yang mengatur tentang hak Anak dan undang undang Perlindungan anak untuk dapat diganti menjadi undang-undang Istimewa seperti halnya undang-undang teroris yang tidak ada hukuman selain mati atau di hukum mati (eksekusi mati).

Walaupun selama ini telah dilakukan usaha - usaha dan juga disusun banyak peraturan perundangan yang mengatur tentang HAM, tetapi masih banyak sekali terjadi tindakan - tindakan yang terhitung melanggar HAM terutama pada anak -anak, misalnya:

a) Perdagangan anak, Beberapa waktu lalu marak terjadi penculikan pada anak - anak yang kemudian dijual. Namun, tidak jarang ada orang tua yang menjual anaknya karena keadaan ekonomi mereka.

b) Banyak anak jalanan yang terlantar, Anak - anak jalanan yang meminta minta atau menjual koran di lampu merah, padahal mereka seharusnya bisa menikmati kasih sayang dalam keluarga dan bisa menikmati pendidikan.

c) Penyiksaan dan perlakuan buruk, Hal ini biasanya dilakukan oleh orang tua. Terkadang hanya karena anak 
melakukan tindakan yang tidak sesuai, anak kemudian dihukum dengan menggunakan kekerasan.

d) Tindakan asusila pada anak, Misalnya tindakan sodomi dan pemerkosaan terhadap anak di bawah umur. Bahkan yang terjadi pelakunya adalah orang tua mereka sendiri.

e) Minimnya pendidikan, Banyak sekali anak - anak yang tidak bisa menikmati pendidikan karena kesulitan perekonomian, selain itu juga minimnya sarana dan prasarana pendidikan yang membuat anak - anak tersebut terpaksa tidak sekolah.

f) Penganiayaan anak dan mempekerjakan anak di bawah umur, Survey terhadap pekerja seks komersial (PSK) di lokalisasi Doli (Surabaya) ditemukan bahwa 25\% dari mereka pertama kali bekerja berumur kurang dari 18 tahun (Ruth Rosenberg, 2003).

g) Pernikahan dini, Hal ini banyak terjadi di pedesaan, menurut hasil survei disebutkan bahwa 46,5\% perempuan menikah sebelum mencapai 18 tahun dan $21,5 \%$ menikah sebelum mencapai 16 tahun. Kasus yang cukup menghebohkan adalah pernikahan yang dialami oleh Lutfiana Ulfa dengan Syekh Puji.

h) Peradilan anak yang tidak berbasis HAM, Kondisi penjara yang sangat tidak layak di penjara anak/Lapas anak
Kota Medan, yang berlokasi di kawasan Tanjung Gusta. Terletak satu kompleks dengan penjara orang dewasa, dari segi kapasitas daya tampung hanya 250 orang, namun penjara anak di Kota Medan dihuni hampir 600 anak. Ruangan sel penjara berukuran $4 \times 3 \mathrm{~m}^{2}$ yang diisi $8-10$ orang anak dengan kamar mandi tanpa penutup di dalamnya, tentunya sangat tidak nyaman dan mengganggu kesehatan,

i) Pembuangan bayi, Berdasarkan catatan Komisi Nasional Perlindungan Anak (Komnas PA), kasus pembuangan bayi di Indonesia yang umumnya dilakukan kalangan orang tua jumlahnya cenderung meningkat. Kebanyakan bayi yang dibuang adalah hasil hubungan gelap atau ada juga yang dikarenakan keadaan ekonomi yang memaksa orang tua untuk membuang bayinya.

j) Gizi buruk (marasmus kwasiokor), Berdasarkan dari UNICEF sebagai badan PBB untuk perlindungan anak, jumlahnya mencapai 10 juta jiwa di Indonesia. Dalam data Komnas Perlindungan Anak, salah satu wilayah yang paling terjadi kasus gizi buruk itu adalah Sumatera Barat. Indonesia sebagai negara yang kaya akan kekayaan alam sangat tragis jika sampai banyak sekali anak - anak yang mengalami gizi buruk, 
k) Penularan HIV/AIDS. Biasanya penyakit dibawa dari ibu (faktor keturunan). Terdapat 18.442 kasus orang tua yang menderita penyakit mematikan tersebut hingga September 2009. Mereka tentu berpotensi menularkan terhadap anak berdasarkan laporan yang didapatkan dari Kementerian Kesehatan.

Berdasarkan beberapan permasalahan yang timbul diatas, maka diperlukan adanya perubahan terhadap Undang-Undang HAM yaitu harus lebih menekankan tentang hukuman. Adapun hukuman yang dianggap dapat melindungi hak-hak anak seperti pemberlakuan hukuman mati bagi pelaku kejahatan anak, sebab hukuman mati bukan merupakan pelanggaran HAM bila itu menyangkut hal yang luar biasa, seperti kejahatan terhadap anak-anak.

\section{KESIMPULAN DAN SARAN}

\subsection{Kesimpulan}

Berdasarkan uraian-uraian diatas dapat disimpulkan bahwa kejahatan terhadap anak merupakan kejahatan luar biasa terutama terhadap anakanak yang masih bayi. Meskipun kejahatan tersebut merupakan kejahatan luar biasa tidak lantas hukumannya menjadi luar biasa. Berdasarkan beberapa kasus kejahatan terhadap anak, pelakunya hanya diberi hukuman penjara 5 (lima) tahun atau lebih ringan.

Dengan ringannya hukuman bagi pelaku kejahatan sehingga tingkat kejahatan setiap tahunnya meningkat. Untuk mengurangi tingkat kejahatan terhadap anak diperlukan adanya hukuman mati bagi pelakunya serta diperlukan revisi didalam UndangUndang Hak Asasi Manusia sehingga menguatkan bahwa hukuman mati bagi pelaku kejahatan terhadap anak diperbolehkan/dibenarkan.

\subsection{Saran}

Undang-Undang Hak Asasi Manusia diperlukan adanya revisi terutama dalam hal pemberlakukan hukuman mati bukan merupakan bagian dari Hak Asasi Manusia khususnya kejahatan terhadap anak. Dengan adanya hukuman mati terhadap kejahatan anak kiranya dapat membawa dampak perubahan terhadap berkurangnya kejahatan yang dilakukan terhadap anak.

\section{DAFTAR PUSTAKA}

Asshiddiqie, Jimly, 2017. Hak Asasi Manusia dalam Konstitusi Indonesia, Jakarta: majda El Muhjaj

Qamar, Nurul, 2013. Hak Asasi Manusia dalam Negara Hukum Demokrasi, Jakarta Timur : Sinar Grafika

Sunggono, Bambang dan Harianto, Aries. Bantuan Hukum dan Hak Asasi Manusia, Bandung: Mandar maju 
Undang-undang Nomor 39 tahun 1999 Tentang Hak Asasi Manusia

Undang-undang Nomor 35 tahun 2014 tentang Perubahan Undang-undang Nomor 23 tahun 2004 Tentang Perlindungan Anak

http://hanyblush.blogspot.co.id/2011/01/huku m-perlindungan-anak-dalamhukum.html

http://smpkebondalem.blogspot.co.id/2009/03 /uu-no-39-tahun-1999-pasal-45-66.html

https://daerah.sindonews.com/topic/1827/kek erasan-anak-dan-perempuan

https://kikizone.wordpress.com/2011/11/03/h ak-anak/ 